American Journal of Applied Sciences 4 (8): 565-569, 2007

ISSN 1546-9239

(C) 2007 Science Publications

\title{
Study the Effects of Ramadan Fasting on the Serum Glucose and Lipid Profile among Healthy Jordanian Students
}

\author{
Kamal Mohmoud Saleh Mansi \\ Department of Biological Sciences, Al al-Bayt University Al-Mafraq - Jordan
}

\begin{abstract}
Ramadan is the holiest month in the Islamic calendar and Muslims fast during this month. We designed this study to evaluate the effect of Ramadan fasting on plasma lipids profile and serum glucose among healthy Jordanian students. Ramadan fasting entails major changes in sleep pattern, physical activity and eating habits, which may cause changes in metabolism both in health and disease. This cohort study was performed during Ramadan in October 2006 (Islamic year 1427). The subjects were 70 healthy Jordanian students (male and female) from three Jordanian universities who fasted during Ramadan. Their mean age was $21 \pm 1.6$ years. We evaluated some anthropometric parameters as body weight $(\mathrm{Kg})$, pulse rate (per minute) and systolic and diastolic blood pressure $(\mathrm{mmHg})$. All parameters at 4 week of Ramadan were significantly lower than pre-Ramadan values, 2 weeks after Ramadan fasting, body weight and other parameters had a trend to recoup to pre-Ramadan status; however, they were still lower than the pre-Ramadan values. We evaluated blood glucose, triglycerides (TG), cholesterol, low-density lipoprotein LDL), high-density lipoprotein (HDL), and Triglycerides at 1 day before, at week 1, 2, 4 of the Ramadan month and after tow weeks after the end of Ramadan. It was found that high-density lipoprotein (HDL) cholesterol increased significantly during Ramadan, which indicated positive association with pulse rate and fat intake and negative association with systolic blood pressure and weight. . The LDLc was significantly reduced at the end of fasting. A reduction in the average TC value was observed at the end of fasting but the difference was not statistically and there no significant rise in the TG and blood sugar values at the end of fasting. This study indicated that Ramadan fasting led to a decrease weight, LDLc significantly, and significant not statistically reduction in the average TC value, and significantly increasing in HDLc was noted during Ramadan. There was a non-significant rise in the TG, and blood sugar value at the end of fasting. It seems that the effect of Ramadan fasting on serum lipid levels may be closely related to the nutritional diet or biochemical response to starvation.
\end{abstract}

Key words: Ramadan fasting, cholesterol, high-density lipoprotein (HDL), low density lipoprotein (LDL), triglycerides (TG)

\section{INTRODUCTION}

Ramadan fasting is one of the 5 pillars of Islam and one of the most significant ibadat (worships) of Islam ${ }^{[1]}$ Throughout the world, millions of Muslims fast during Ramadan to fulfill this religious obligation. Because the lunar calendar determines the month of Ramadan and is about 11 days shorter than the solar year, Ramadan is not fixed to any season. The timing of daily fasting varies from country to country and with the season in which the month of Ramadan falls. Thus, depending upon the season and the geographical position of the country, the length of the fast varies from 12 to 19 hours per day ${ }^{[2]}$. During Ramadan, Muslims abstain from food and drink from dawn until sunset.
Traditionally the practice is to eat 2 meals, 1 before dawn, suhore, and 1 just after sunset, iftar. Often Muslims eat a greater variety of foods in their meals during Ramadan than in other months. As a result, the Ramadan fast provides an excellent opportunity to study the effects of various diets on the human body and can serve as an excellent research model for metabolic and behavioral studies ${ }^{[3]}$. Ramadan fasting and starvation are not synonymous. Many physiological and psychological changes take place during Ramadan, most probably due to the changes in eating patterns, eating frequency and sleep patterns ${ }^{[4]}$. Some studies in the eastern Mediterranean area have indicated improved high-density lipoprotein (HDL) cholesterol during Ramadan fasting ${ }^{[5,6]}$. Few studies have shown the 
effect of Ramadan fasting on serum glucose ${ }^{[7-11]}$. One study has shown a slight decrease in serum glucose in the first days of Ramadan, followed by normalization by the twentieth day and a slight rise by the twentyninth day of Ramadan ${ }^{[12]}$. The lowest serum glucose level in this study was $63 \mathrm{mg} / \mathrm{dl}$. Others have shown a mild increase [13] or variation in serum glucose concentration, but all of them fell within physiological limits ${ }^{[10]}$. From the foregoing studies, one may assume that the stores of glycogen, along with some degree of gluconeogenesis, maintain normal limits of serum glucose when a fast follows a large pre-dawn meal. However, slight changes in serum glucose may occur in individuals depending upon food habits and individual differences in metabolism and energy regulation.

Weight losses of $1.7 \mathrm{~kg} .{ }^{[14]} 1.8 \mathrm{~kg}$. $, 2.0 \mathrm{~kg},{ }^{[15]}$ and $3.8 \mathrm{~kg}^{[16]}$ have been reported in normal weight individuals after they have fasted for the month of Ramadan. In one study that was over-represented by females, no change in body weight was seen ${ }^{[15]}$.It has also been reported that overweight persons lose more weight than normal or underweight subjects ${ }^{[15]}$. The amount of Energy (calorie) intake have been reported in some of the literature, indicating a decrease in energy intake ${ }^{[17,18]}$. More studies show no change or a slight decrease in concentrations of total cholesterol and triglycerides ${ }^{[19-21]}$. Increase in total cholesterol levels during Ramadan seldom occurs ${ }^{[22]}$.As in healthy persons ${ }^{[4,6]}$.Few studies have reported increases in high-density-lipoprotein (HDL) cholesterol in diabetics during Ramadan ${ }^{[23,24]}$. One report indicates an increase in low-density-lipoprotein (LDL) cholesterol and a decrease in HDL-cholesterol ${ }^{[18]}$. Few studies have shown the effect of Ramadan fasting Serum creatinine, uric acid, blood urea nitrogen, protein, albumin, alanine amino-transferase; aspirate amino-transferase values do not show significant changes during the fasting period $^{[19,21,25]}$. Slight non-significant increases in some biological parameters may be due to dehydration and metabolic adaptation and have no clinical presentation.

\section{MATERIALS AND METHODS}

This study was performed during Ramadan of October 2006 (Islamic year 1427). The subjects were 70 healthy students (male and female) of three different Jordanian Universities their mean age $21.3 \pm 1.6$ years and who indicated that they were going to fast during Ramadan. We excluded students with any acute or chronic disease or medication during the study. Blood samples were collected from all subjects in tubes 1 day before, at week 1, 2, 4 of the Ramadan month and after tow weeks after the end of Ramadan, serum separated from samples through centrifugation and assays were immediately done or the serum stored at less than or equal to -20C. Serum total cholesterol (TC), highdensity lipoprotein cholesterol (HDL-C), low-density lipoprotein cholesterol (LDL-C) triglycerides (TG) and serum glucose of all the subjects were measured using the commercially available kits (Enzymatic colorimetric method according to Trinder method).

\section{RESULTS}

The effect of Ramadan fasting on lipid profile and blood sugar was studied on 70 healthy volunteer's student (male and female). Their mean age was $21.3 \pm 1.6$ years. The blood parameters of the volunteers in the 1 day before, at week 1, 2 and 4 of the Ramadan month and after tow weeks after the end of Ramadan were further studied and compared. We evaluated some anthropometric parameters as body weight $(\mathrm{Kg})$, pulse rate (per minute) and systolic and diastolic blood pressure $(\mathrm{mmHg})$.

All parameters at 4 week of Ramadan were significantly lower than pre-Ramadan values, 2 weeks after Ramadan fasting, body weight and other parameters had a trend to recoup to pre-Ramadan status; however, they were still lower than the preRamadan values. (Table1) Serum high-density lipoprotein (HDL) cholesterol increased significantly during Ramadan in both male and female, (Table 2). In our study there was a significant reduction in LDLc an effect that was observed in the study conducted by ${ }^{[25]}$ who reported significant reduction in LDLc, which was maintained one month after Ramadan. A reduction in the average TC value was observed at the end of fasting but the difference was not statistically and there no significant rise in the TG and blood sugar values at the end of fasting similar to the effect observed in the other studies ${ }^{[26,27]}$.

\section{DISCUSSION}

The mean difference between pre- Ramadan and during Ramadan body weights was $2.2 \mathrm{~kg}$ in male and $1.2 \mathrm{~kg}$ in female. Significant reductions in body weight. Similarly, many studies have reported weight loss during the month of Ramadan fasting ${ }^{[27]}$. In contrast to this, one Saudi Arabian study reported weight gain during Ramadan ${ }^{[28]}$ and still others did not find any significant change in body weight $(29,30)$.In one study among healthy males, a significant reduction in skin fold thickness was reported during Ramadan fasting ${ }^{[31]}$. A study of Tunisian women suggested that increased fat 
Am. J. Applied Sci., 4 (8): 565-569, 2007

Table 1: Anthropometric and other measurements of the healthy male volunteers

\begin{tabular}{|c|c|c|c|c|c|}
\hline Measurements & $\begin{array}{l}1 \text { day pre } \\
\text { Ramadan } \\
\end{array}$ & $\begin{array}{l}\text { First week } \\
\text { of Ramadan }\end{array}$ & $\begin{array}{l}\text { Second week } \\
\text { of Ramadan }\end{array}$ & $\begin{array}{l}\text { Forth Week } \\
\text { of Ramadan }\end{array}$ & $\begin{array}{l}2 \text { weeks } \\
\text { after Ramadan }\end{array}$ \\
\hline $\begin{array}{l}\text { Body weight } \\
\text { (Kg) }\end{array}$ & $76.64 \pm 9.53$ & $74.43 \pm 11.16$ & $73.32 \pm 10.3$ & $72.66 \pm 9.2$ & $73.64 \pm 8.83$ \\
\hline $\begin{array}{l}\text { Pulse rate } \\
\text { (Per minute) }\end{array}$ & $82.16 \pm 7.62$ & $80.32 \pm 6.62$ & $78.62 \pm 5.82$ & $77.24 \pm 6.2$ & $77.42 \pm 5.6$ \\
\hline $\begin{array}{l}\text { Systolic } \\
\text { pressure (mmHg) }\end{array}$ & $126.32 \pm 17.46$ & $124.23 \pm 15.31$ & $116.84 \pm 14.4$ & $112.41 \pm 15$ & $118.62 \pm 2.55$ \\
\hline $\begin{array}{l}\text { Diastolic } \\
\text { pressure }(\mathrm{mmHg})\end{array}$ & $84.53 \pm 12.62$ & $82.32 \pm 8.40$ & $76.41 \pm 9.34$ & $76.50 \pm 10.6$ & $78.43 \pm 9.38$ \\
\hline
\end{tabular}

Table 2: Serum glucose and serum lipids of the healthy male student's pre-Ramadan, during Ramadan, and after Ramadan

\begin{tabular}{|c|c|c|c|c|c|}
\hline Measurements & $\begin{array}{l}1 \text { day pre } \\
\text { Ramadan }\end{array}$ & $\begin{array}{l}\text { First week } \\
\text { of Ramadan }\end{array}$ & $\begin{array}{c}\text { Second week } \\
\text { of Ramadan }\end{array}$ & $\begin{array}{l}\text { Forth Week } \\
\text { of Ramadan } \\
\end{array}$ & $\begin{array}{l}\text { 2weeks after } \\
\text { Ramadan }\end{array}$ \\
\hline $\begin{array}{l}\text { Glucose } \\
(\mathrm{mg} / \mathrm{dl})\end{array}$ & $94.32 \pm 6.23$ & $88.34 \pm 6.14$ & $86.11 \pm 4.85$ & $85.84 \pm 6.43$ & $91.26 \pm 10.82$ \\
\hline $\begin{array}{l}\text { Total cholesterol } \\
(\mathrm{mg} / \mathrm{dl})\end{array}$ & $164.34 \pm 28.24$ & $162.27 \pm 24.41$ & $160.42 \pm 18.21$ & $159.57 \pm 19.53$ & $176.46 \pm 26.49$ \\
\hline $\begin{array}{l}\text { HDLCholesterol } \\
(\mathrm{mg} / \mathrm{dl})\end{array}$ & $36.13 \pm 6.42$ & $38.14 \pm 8.82$ & $43.42 \pm 10.61$ & $48.86 \pm 12.34$ & $43.68 \pm 10.42$ \\
\hline $\begin{array}{l}\text { LDLCholesterol } \\
(\mathrm{mg} / \mathrm{dl})\end{array}$ & $112.91 \pm 32.57$ & $110.81 \pm 30.65$ & $102.34 \pm 28.22$ & $98.63 \pm 25.48$ & $104.72 \pm 23.43$ \\
\hline $\begin{array}{l}\text { Triglycerides } \\
(\mathrm{mg} / \mathrm{dl})\end{array}$ & $148.54 \pm 54.72$ & $146.32 \pm 62.41$ & $145.52 \pm 43.43$ & $139.36 \pm 52.29$ & $154.82 \pm 56.68$ \\
\hline
\end{tabular}

Oxidation during Ramadan fasting results in an adaptive mechanism for body weight maintenance ${ }^{[30]}$ .Our observation of decreases in systolic and diastolic blood pressure is supported by the findings of ${ }^{[7]}$.

The body has regulatory mechanisms that activate during fasting. There is efficient utilization of fat ${ }^{[30]}$. And basal metabolism slows down during fasting ${ }^{[27]}$ contrary to the popular thinking, it was found that intake of a moderately. High fat diet around $36 \%$ of the total energy improved blood cholesterol profile ${ }^{[32,33]}$ .The normal recommended guidelines for daily fat intake is $30 \%$ or less energy ${ }^{[32]}$.On weight basis, suggested fat intake during Ramadan is almost the same as during non-Ramadan days ${ }^{[33]} .{ }^{[31]}$ Investigated the effect of hypocaloric diet on men $[1800 \mathrm{Kcal} /$ day with $30 \%$ fat content] and found no significant effect on total cholesterol level The improved HDL cholesterol profile in our study is supported by many studies ${ }^{[34,35]}$ noted similar increases in HDL cholesterol profiles in 2 nonRamadan studies ${ }^{[33]}$. Nonetheless, some studies have reported decreases ${ }^{[3 i]}$.In multiple regressions analysis HDL cholesterol was positively associated with pulse rate and fat intake and negatively with weight loss and higher systolic blood pressure. Improvement in HDL cholesterol profile with higher fat intake agrees with the findings of ${ }^{[36]}$.

The significant reduction in LDLc occurred despite the fact that tendency to consume fried foods was increased during Ramadan. Consumption of increased fried foods suggests a higher intake of fats as compared to non-Ramadan days. It appeared as if the quality and quantity of fat intake in Ramadan govern blood cholesterol level. In another study suggested that feeding behavior that occurs during Ramadan beneficially affects serum apolipoprotein metabolism and may contribute to prevention of coronary heart 
disease. ${ }^{[37]}$ Examined the relation of Fasting to coronary events and found that the number of cases with acute coronary heart disease events were significantly lower in Ramadan than before or after Ramadan. A reduction in the average TC value was observed at the end of fasting but the difference was not statistically and the non-significant elevated serum TG may be attributed to the lipolytic effect of prolonged fasting and this was in line with study ${ }^{[26]}$ who observed increase in serum TG level at the end of fasting.

Our analysis founded that a slight decrease in serum glucose in Ramadan among our subjects. It has been found that a slight decrease in serum glucose occurs in normal adults a few hours after fasting has begun. However the reduction in serum glucose ceases due to increased gluconeognesis in the liver. This occurs because of a decrease in insulin concentration and a rise in glucagons and sympathetic activity ${ }^{[14]}$. Few studies have shown the effect of Ramadan fasting

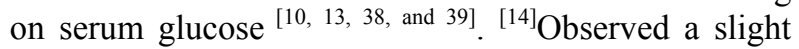
decrease in serum glucose in the first days of Ramadan followed by normalization by the 20th day and a slight rise by the 29 th day of Ramadan. Others ${ }^{[40]}$ have shown a mild increase or variation in serum glucose concentration ${ }^{[41]}$ all of them fall within physiologic limits ${ }^{[42-44]}$. In our study there was a non-significant rise in blood sugar value at the end of fasting similar to the effect observed in the other studies.

\section{CONCLUSION}

Ramadan fasting appears to have significant effect on LDLc that should translate into a significant reduction in coronary risk. Ramadan fasting contributed to better blood lipid profiles under the prevailing limited energy intake conditions of the study. One of the contributing factors may be higher fat intake To shed more light on the pathophysiological changes in Ramadan fasting, it is recommended that a multicentric international controlled clinical trial be employed to assess the effect of difference in gender, race, physical activity, food habits, sleep pattern and other important variables on physiologic and pathologic conditions during Ramadan fasting.

\section{ACKNOWLEDGMENTS}

Financial support from Al al-Bayt University is gratefully acknowledged, and the students who participated in the study are gratefully thanked. Also we would like to thank Jordan University hospital for all support in performing needed analysis.

\section{REFERENCES}

1. Aldouni, A., N. Glim, R. Saile, N. Hda, H.J. Parra and A. Benslimane, 1998. Beneficial effect on serum apo AI, apo B. and Lp AI levels of Ramadan fasting. Clin. Chim. Acta, 271:179-189.

2. Aldouni, A., N. Ghalim, A. B. Lecerfjm and R. Saile, 1997. Fasting during Ramadan induces a marked increase in high-density -lipoprotein cholesterol and decrease in low-density-lipoprotein cholesterol. Ann. Nutr. Metab. 41: 242-249.

3. Aldouni, A., 1997. et al. Fasting during Ramadan induces a marked increase in high- density lipoprotein cholesterol and decrease in low-density lipoprotein choles- terol. Annals of nutrition and metabolism, 41:242-9.

4. Akanji, A.O., O.A. Mojiminiyi, and N. Abdella, 2000. Beneficial changes in serum apo A-1 and its ratio to apo B and HDL in stable hyper-lipidaemic subjects after Ramadan fasting in Kuwait. Euro. J. Clin. Nutr. 54: 508-13.

5. Akhtar, M.and G.Q. Malik, 1991. Ramadan fasting and thyroid hormone profile. JPMA. 41:213-216.

6. AL Hader, A.F.A., N.A. Abu-Farsakh, S.Y. Khatib and Z.A. Hassan, 1994. The effects of Ramadan fasting on certain biochemical parameters in normal subjects and type II diabetic patients. First International Congress on Health and Ramadan. Jan. 19-22., Casablanca, Morocco, pp: 26.

7. Athar, S. and M. Habib, 1994. Management of stable type 2 diabetes mellitus NIDDM during Islamic fasting in Ramadan. Paper presented at the First International Congress on Health and Ramadan, 19-22 January, Casablanca, Morocco.

8. Ati, J., C. Beji and J. Danguir, 1995. Increased fat oxidation during Ramadan fasting in healthy women. An adaptive mechanism for body weight maintenance. IS. J. Clin. Nutr. 62:302-7

9. Azizi, F., 1978. Effect of dietary composition on fasting-induced changes in serum thyroid hormones and thyrotropin. Metabolism. 27:934945

10. Azizi, F., 1996. Medical aspects of Islamic fasting. Med. J. IR. Iran. 10: 241-246.

11. Azizi, F. and H.A. Rasouli, 1987. Serum glucose, bilirubin, calcium, phosphorus, protein and albumin concentrations during Ramadan. Med. J. IR. Iran. 1:38-41

12. Bouguerra, R., C. Ben. Slama, A. Belkadhi, H. Jabrane, L. Beltaifa, C. Ben Rayana and T. Doghri, 1997. Metabolic control and plasma lipoprotein during Ramadan fasting in non-insulin dependent diabetes. Second International Congress on Health and Ramadan. Istanbul, Turkey, pp: 33. 
13. Congress on Health and Ramadan. 1997, Istanbul, Turkey, pp: 33.

14. Davidson, JC. 1979. Muslims, Ramadan and diabetes mellitus. BMJ. 2: 1511-1512.

15. Dehghan, M., M. Nafarabadi, L. Navai and F. Azizi, 1994. Effect of Ramadan fasting on lipid and glucose concentrations in type II diabetic patients. J. of the Faculty of Medicine, Shaheed Beheshti University of Medical Sciences, Tehran, I.R. Iran. 18:42-47.

16. El-Ati, J., C. Beji and J. Danguir, 1995. Increased fat oxidation during Ramadan fasting in healthy women: an adaptive mechanism for body-weight maintenance. Am. J. Clin. Nutr. 62: 302-7.

17. Ewis, A. and NM. Afifi, 1997. Ramadan fasting and non-insulin-dependent diabetes mellitus: Effect of regular exercise. Second International Congress on Health and Ramadan. Istanbul, Turkey, pp: 76.

18. Frost, G. and S. Pirani, 1997. Meal frequency and nutritional intake during Ramadan: A pilot study. Human nutrition, Appli. Nutr. 41: 47-50.

19. Hallak, M.H. and M.Z.A. Nomani, 1988. Body weight loss and changes in blood lipid levels in normal men on hypocaloric diets during Ramadan fasting. Am. J. Clin. Nutr. 48: 1197-210.

20. Haouri, M., F. Haourai-Oukerro, A. Mebazaa and K. Nagati, 1997. Circadian evolution of serum level of glucose, insulin, cortisol and total proteins in healthy, fasting volunteers. Second International Congress on Health and Ramadan. Istanbul, Turkey, pp: 31.

21. Hussein, R., M.T. Duncan and S.L. Chang, 1987. Effects of fasting in Ramadan on tropical Asiatic Moslems. British j. nutrition, 58:41-8.

22. Khatib, F., 1997. Effect of fasting in Ramadan on blood glucose and plasma lipids in diabetics with NIDDM. Second International Congress on Health and Ramadan. Istanbul, Turkey, pp: 42.

23. Khogheer, Y., M.I. Sulaiman and S.F. Al-Fayez, 1987. Ramadan fasting state of controls. Ann Saudi Med. 7(suppl.): 5-6.

24. Klocker, N., J. Belkhadir, H. El Ghomari, A. Mikou, M. Naciri and M. Sabri, 1997. Effects of extreme chrono-biological diet alternations during Ramadan on metabolism in NIDDM diabetes with oral treatment. Second International Congress on Health and Ramadan. Istanbul, Turkey, pp: 78-79.

25. Mafauzy, M., W.B. Mohammed, MY. Anum, A. Zulkifli and A.H. Ruhani, 1990. A study of fasting diabetic patients during the month of Ramadan. Med. J. Malaya. 45:14-17

26. Laajam, M.A., 1990. Ramadan fasting and non insulin-dependent diabetes: Effect of metabolic control. East Afr. Med. J. 67: 732-736.

27. Maislos, M., Y. Abou-Rabiah, I. Zuili, S. Iordash and S. Shany, 1998. Gorging and plasma HDLcholesterol - the Ramadan model. Euro. J. Clin. Nutr. 52:127-130.
28. Maislos, M., N. Khamaysi, A. Assali, Y. AbouRabiah, I. Zvili and S. Shany, 1993. Marked increase in plasma high-density-lipoprotein cholesterol after prolonged fasting during Ramadan. Am. J. Clin. Nutr. 57: 640-642.

29. Maislos, M., 1993. et al. Marked increases in plasma high-density lipoprotein cholesterol after prolonged fasting during Ra-madan. Am. J. Clin. Nutr. 57: 640-2.

30. Maislos, M., 1998. et al. Gorging and plasma HDL cholesterol-the Ramadan model. Euro. J. Clin. Nutr. 52:127-30.

31. Muazzam, G., 1991.Ramadan fasting and medical science. Ilfracombe, Devon, Arthur H. Stock well Limited, 5-32.

32. Murphy, M.C., 1996. et al. Meal frequency: does it determine postprandial lipaemia? Euro. J. Clin. Nutr. 50:491-7.

33. Nagra, S.A., Z. Rahman and J. Mehmood, 1998. et al. Study of some biochemical parameters in young women as affected by Ramadan fasting. Int. J. Ramadan fasting Res; 2: 1-5.

34. National Academy of Science. Recommended Dietary Allowances, 1989. National Academic press, Washington, D.C., 10ThEd.

35. Nomani, M.Z.A., 1999. Diet during Ramadan .Int J. Ramadan fast-Ing Res., 3: 1-6.

36. Nomani, M.Z.A., 1997. Dietary fat, blood cholesterol and uric acid levels during Ramadan fasting. International $\mathrm{j}$. Ramadan fasting research, 1: $1-6$.

37. Nomani, M.Z.A., S.K. Baloch and I.P. Siddiqui, 1992. Changes in serum cholesterol level and dietary vegetable fat at restricted energy intake condition during Ramadan fasting. Int. J. Sci Tech., 4: 30-36.

38. Rashid, H.U., S. Ahmed and P.K. Chhetri, 1996. Ra-madan fasting: Study of different biochemical parameters. J.1 of inter- national postgraduate medical research, 11: 14-6.

39. Suleiman, R.A., 1988. Effect of Ramadan fasting on thyroid function in healthy male individuals. Nutr. Res. 8:549-552.

40. Scott, T.G., 1981. The effect of Muslim fast of Ramadan on routine laboratory investigation. King Abdulaziz Med. J. 1:23-35.

41. Shoukry, M.I., 1986. Effect of fasting in Ramadan on plasma lipoproteins and apoproteins. Saudi Med. J. 7:561-567.

42. Takruri, H.R., 1989. Effect of fasting in Ramadan on body weight. Saudi Med. J. 10: 491-494.

43. Temizhan, A., O. Donderici, D. Ouz and B. Demirbas, 1999. Is there any effect of Ramadan fasting on acute coronary heart disease events? Int. J. Cardiol. 70:149-53.

44. Usual, A., M. Endogen, G. Shin, N. Camel and G. Endogen, 1997. The clinical, metabolic and hormonal effects of fasting on 41 NIDDM patients, during the Ramadan 1997. Second International Congress on Health and Ramadan. Istanbul, Turkey, pp: 44-45.27 